\title{
News Reports
}

\section{USGS Releases Scientific Monograph on Sage-Grouse Ecology and Conservation}

n November, the US Geological Survey (USGS) announced the early release of select prepublication chapters of an upcoming book on the Ecology and Conservation of Greater Sage-Grouse: A Landscape Species and Its Habitats ${ }^{1}$ at http://sagemap.wr.usgs.gov/monograph. aspx. The book, written by 38 federal, state, university, and nongovernmental experts, contains new scientific information about greater sage-grouse populations, sagebrush habitats, and relationships among sage-grouse, sagebrush, and land use. Final versions of the early release chapters and an additional summary chapter will be published by the University of California Press as a scientific monograph in the Cooper Ornithological Society's series Studies in Avian Biology.

Greater sage-grouse populations have declined substantially in many areas in the West, though populations in some locations remain relatively stable. The current distribution of the species, which is half of its estimated historical range, extends across 11 states and part of 2 Canadian provinces. "The underlying cause for population declines in this western species is loss of suitable sagebrush habitat to meet seasonal requirements for food, cover, and nesting," said Steven Knick, a lead editor of the monograph and a scientist at the USGS Forest and Rangeland Ecosystem Science Center in Boise, Idaho. The publication not only describes the bird's population trends, but also its sagebrush habitat and limitations to conservation, including effects of rangeland fire, climate change, invasive plants, disease, and land uses such as energy development, livestock grazing, and agriculture.

\section{Climate Change, Nitrogen Loss Threaten Plant Life in Arid Soils}

In arid environments, nitrogen can be the second most limiting nutrient for biological activity. The majority of the flux of nitrogen in these ecosystems is typically thought to be driven by microorganisms in the soil. But in their Science paper, ${ }^{2}$ Carmody McCalley and Jed Sparks of Cornell University's Department of Ecology and Evolutionary Biology present results from the Mohave Desert that suggest higher temperatures cause nitrogen to escape as gas from the soil. This abiotic pathway of nitrogen loss from soil to air not only helps us better understand arid ecosystem nitrogen budgets, but also should change our views of global nitrogen cycling and predicted impacts of increased

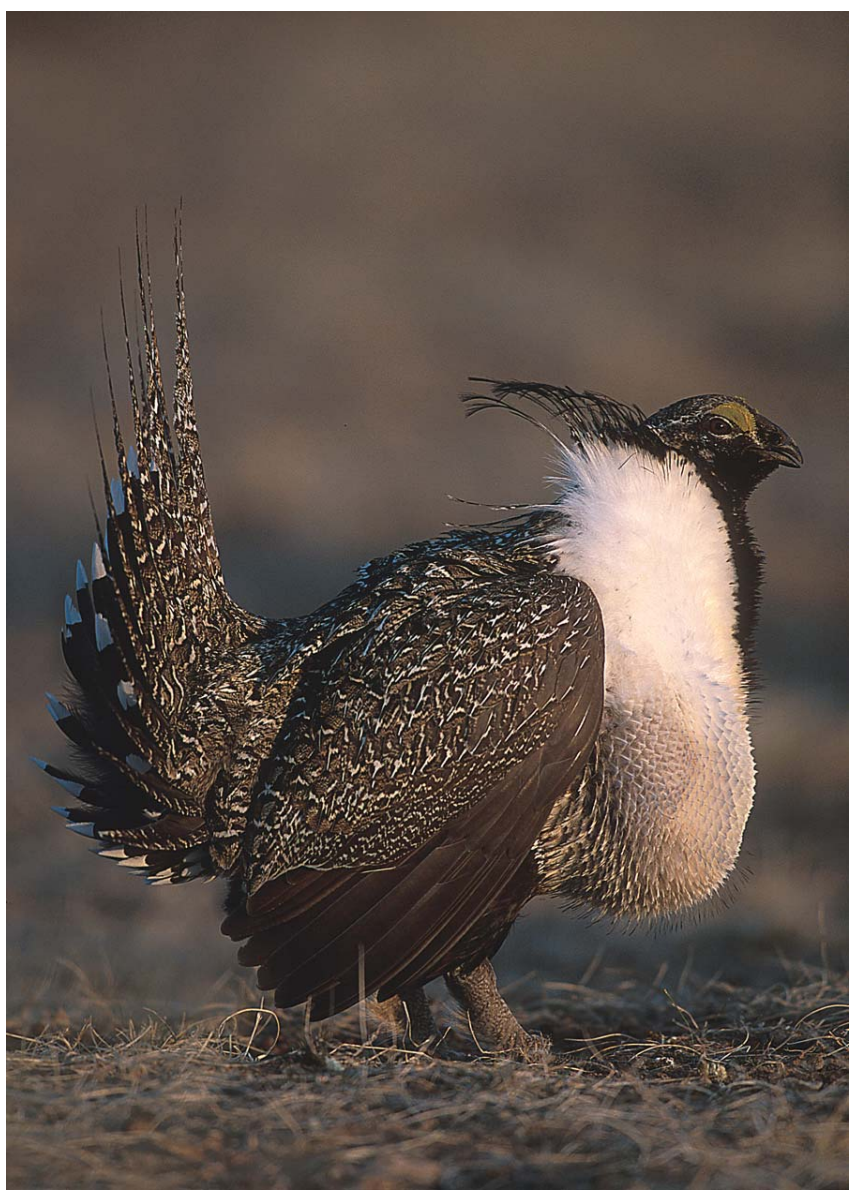

Male greater sage-grouse. Photo copyright Terry Steele.

temperatures on nitrogen bioavailability. Temperature increases due to climate change may lead to more nitrogen losses in arid ecosystems, making their soils even more infertile. This new information also suggests that climate change models need to be altered since most now use algorithms that only consider biological factors to predict nitrogen gases coming from soils. The study was funded by the National Science Foundation's Division of Environmental Biology and Cornell's Andrew Mellon Student Research Grants.

\section{Food Security and Climate Change}

Two recent reports focus on the links between food security and climate change mitigation and adaptation. The twin battles to improve food security for a growing world 
population and contain climate change can be fought on the same front - the world's farmland and rangeland, says a report from the United Nation's (UN) Food and Agriculture Organization. ${ }^{3}$ The report, "Food security and agricultural mitigation in developing countries: options for capturing synergies," explores potential synergies between food security, adaptation, and climate change mitigation from land-based agricultural practices, which could help generate multiple benefits needed to address the multiple demands placed on agriculture. The most important technical options for climate change mitigation from agriculture are improvements in cropland and grazing land management and the restoration of organic soils and degraded lands. Other options involve difficult trade-offs, with benefits for mitigation but potentially negative consequences for food security and development. In some cases, there are synergies in the long-run, but trade-offs in the short-run. Rangeland restoration may improve carbon sequestration, but it also involves short-term reductions in herder incomes by limiting the number of livestock. Some trade-offs can be managed through measures to increase efficiency or through payment of incentives or compensation. Despite its significant potential, agricultural mitigation has remained relatively marginal within the climate change negotiations. To capture the multiple benefits of agriculture, the report recommends a program on agricultural mitigation within the UN Framework Convention on Climate Change Subsidiary Body for Scientific and Technological Advice to help address methodological issues related to implementation. It also proposes country-led piloting of action and field testing using a phased approach linked to national capabilities and supported by capacity building and financial/technology transfers.

In "Eating the planet? How we can feed the world without trashing it, ${ }^{\prime 4,5}$ Friends of the Earth and Compassion in World Farming reveal how we can feed a growing global population by using planet-friendly farming methods and eating less, but better, meat. The report summarizes original research by the Institute of Social Ecology, Alpen Adria Universität Klagenfurt, Vienna, Austria, and the Potsdam
Institute for Climate Impact Research, Germany, and draws out implications and recommendations arising from the research findings. The research models future food production against different diets, farming methods, and land use, and concludes that enough food can be produced to feed the growing world population, with fairer and healthier diets and without factory farms and forest destruction. The researchers found that a diet equivalent to eating meat three times a week would allow forests to remain untouched, animals to be farmed in free-range conditions, and greener farming methods to be used. The report concludes with policy recommendations regarding sustainable and organic farming and ranching, diets (particularly of developed countries), bioenergy, climate change, and future research needs.

\section{References}

1. Knick, S. T., And J. W. Connelly [eds]. 2010. Ecology and conservation of greater sage-grouse: a landscape species and its habitats. In: Studies in Avian Biology. Berkeley, CA, USA: University of California Press.

2. McCalley, C. K., and J. P. Sparks. 2009. Abiotic gas formation drives nitrogen loss from a desert ecosystem. Science 6:837-840.

3. Food and Agriculture Organization. 2009 (prepublication draft). Food security and agricultural mitigation in developing countries: options for capturing synergies. Rome, Italy: Food and Agriculture Organization of the United Nations. Available at: ftp://ftp.fao.org/docrep/fao/012/ak596e/ak596e00.pdf. Accessed 10 November 2009.

4. Compassion in World Farming and Friends of the Earth. 2009. Eating the planet? How we can feed the world without trashing it. Summary report. Available at: http://www.foe.co. uk/resource/briefings/eating_planet_briefing.pdf. Accessed 11 November 2009.

5. Erb, K., H. Haberl, F. Krausmann, C. Lauk, C. Plutzar, J. K. Steinberger, C. Müller, A. Bondeau, K. Waha, and G. Pollack. 2009. Feeding and fueling the world sustainably, fairly and humanely - a scoping study. Social Ecology Working Paper 116. Vienna, Italy: Institute of Social Ecology. http:// www.ciwf.org/eatingtheplanet. Accessed 11 November 2009. 